\title{
ФОРТЕПІАННИЙ ТА КАМЕРНИЙ АНСАМБЛЬ У ЖИТТІ ТА ТВОРЧОСТІ ФРИДЕРИКА ШОПЕНА
}

\section{Польська I. I.}

\section{ВСТУП}

Однією 3 найвищих вершин світового музичного мистецтва, недосяжним еталоном художньої досконалості, емоційного багатства, жанрового багатоманіття й благородства стилю є творчість Фридерика Шопена, репрезентована насамперед фортепіанними творами композитора.

Фортепіанний спадок Шопена, який уже майже два століття $\epsilon$ постійним об'єктом численних музикознавчих досліджень і найважливішою компонентою репертуару піаністів-виконавців, представлений творами трьох типів: 1) сольними творами, що абсолютно домінують у шопенівській фортепіанній творчості; 2) ансамблевими творами як для чотириручного дуету на одному фортепіано, так $\mathrm{i}$ для дуету двофортепіанного; 3) творами для фортепіано 3 оркестром, до яких належать знамениті фортепіанні концерти композитора, а також концертні п'єси, створені Шопеном у ранній період творчості. Об'єктом дослідницької уваги у цій статті $є$ саме творча діяльність Ф. Шопена (композиторська та виконавська) у жанрових сферах фортепіанного та камерного ансамблів.

Фортепіанний ансамбль, котрий, як відзначалося авторкою статті у їі наукових працях, «за своєю роллю в системі жанрів репрезентує як камерно-ансамблеве, так і сольне фортепіанне виконавство, маючи при цьому власні, лише йому притаманні жанрові властивості» ${ }^{1}, \epsilon$ однією 3 «найяскравіших, найсвоєрідніших і самих значущих сфер»² як камерної музики, так і музики концертної орієнтації. «Провідним репрезентантом фортепіанного ансамблю як такого є фортепіанний дует, екзистенція якого відбувається у двох принципово різних жанрових іпостасях, типологічно відмінних одна від одної за своїми змістовими, хронотопічними та виконавськими характеристиками. Цими основними жанровими типами фортепіанного дуету $\epsilon:$ 1) чотириручний фортепіанний дует на одному фортепіано та 2) двофортепіанний дует»³.

\footnotetext{
1 Польська I.I. Фортепіанний дует у системі фортепіанного ансамблю: жанрово-типологічні аспекти (The piano duet in the system of piano ensemble: genre-typological aspects). Культура Украӥни. Серія: Мистеитвознавство : зб. наук. пр. Харків. держ. акад. культури / за заг. ред. В.М. Шейка. Харків : ХДАК, 2018. Вип. 61. С. 170.

${ }^{2}$ Там само, с. 170

Там само, с. 171. 
Саме фортепіанний дует в обох своїх жанрових іпостасях репрезентує фортепіанний ансамбль як такий у композиторській творчості Ф. Шопена. Проте виконавська діяльність великого польського музиканта демонструє значно ширший як за виконавським складом, так i за своїми органологічними характеристиками спектр різновидів фортепіанного ансамблю (на трьох, чотирьох та більше різних інструментах, а також у 8 рук на двох фортепіано).

Водночас у мистецькій діяльності Ф. Шопена поряд із фортепіанним ансамблем знайшли яскраве втілення також камерно-ансамблеві жанри, репрезентовані у його композиторській та виконавській творчості переважно (проте не виключно) музикою для віолончелі та фортепіано.

Більшість ансамблевих творів Шопена написана ним у юні роки в рідній Польщі. Серед них - усі фортепіанні дуети, фортепіанне тріо, твори для віолончелі та фортепіано, а також для флейти та фортепіано. У роки паризької еміграції композитором були створені лише Віолончельна соната та Великий концертний дует для фортепіано та віолончелі (спільно з О. Франкоммом).

Загалом у величезній спадщині Фридерика Шопена твори, написані для фортепіанного та камерного ансамблю, можна буквально перелічити на пальцях. Тим не менше музикознавче висвітлення ролі ансамблевих жанрів у житті та творчості митця видається вельми важливим не лише для створення цілісної панорами композиторського спадку Ф. Шопена, а й для кращого розуміння духовного світу його особистості, а також характеру тієї доби.

\section{1. Фортепіанні дуетні твори Ф. Шопена}

Фортепіанні ансамблеві твори Ф. Шопена репрезентують обидва наявні жанрові типи фортепіанних дуетів - для одного фортепіано у чотири руки та для двох фортепіано. До першого типу належать два варіаційні цикли для фортепіано у чотири руки - Варіації F-dur на власну тему та Варіації D-dur на тему T. Мура, - створені (за прийнятим датуванням) у 1826 р. Другий тип дуетів репрезентований Рондо C-dur ор 73 (1828) для двох фортепіано.

Крім того, в одному зі своїх листів до рідних у Варшаву (від 22 грудня 1830) Шопен згадує про роботу над концертом для двох фортепіано та намір виконати його разом з піаністом Т. Нідецьким: «Коли я напишу концерт для двох фортепіано, то ми разом заграємо його публічно; але спершу мушу виступити соло» ${ }^{4}$. Проте ніяких інших відомостей про такий твір не збереглося. Як зазначає Г. Кухарський у коментарі до

\footnotetext{
${ }^{4}$ Шопен Ф. Письма: В 2-х томах / Сост., вступ. ст., коммент, хронограф Г.С. Кухарского. 4-е изд. Москва : Музыка, 1989. Т. 1. С. 194.
} 
цього листа, ескізи до згаданого концерту Шопен імовірно використав пізніше в Allegro de Concert op. $46^{5}$.

Вже у ранніх (можливо, ще не зовсім зрілих) фортепіанних ансамблях композитора виразно виступають неповторні риси шопенівського стилю. Рукопис першого 3 цих творів - Варіацій F-dur на власну тему для фортепіано у чотири руки, написаних у 1826 р. (зауважимо, що деякі дослідники, зокрема, Я. Івашкевич, датують їх створення 1827 роком $\left.^{6}\right),-$ скоріш за все не зберігся; в усякому разі досі його знайти поки що не вдалося.

Інший твір - Варіації D-dur на тему T. Мура для фортепіано у чотири руки (1826) - теж довгий час вважався загубленим і був опублікований вперше лише у 1965 р., до того ж не в автентичному, а в старанно реконструйованому польським музикознавцем Яном Екером вигляді, оскільки знайдений рукопис, на жаль, зберігся лише частково: у ньому були відсутні дві сторінки тексту (остання сторінка партії Primo та перша - партії Secondo) ${ }^{7}$.

Варіації D-dur були написані молодим Шопеном на тему з дуже популярної в ті роки пісенної збірки відомого ірландського поетаромантика, автора уславленої поеми «Лалла Рук», співака і композитора Томаса Мура (1779-1852), котрий відібрав яскраві мелодії різних народів та додав до них англійські слова. Тема, що надихнула Шопена, позиціонується у збірці як арія, втім, за даними сучасних наукових розвідок, насправді $є$ неаполітанською піснею "La Ricciolella", котра досі $\epsilon$ поширеною в Італії ${ }^{8}$. Безпосереднім поштовхом до створення шопенівських Варіацій стало ознайомлення (ще у 1824 р.) молодим композитором з написаними саме на цю мелодію Варіації на арію Мура для фортепіано в 4 руки уславленого композитора та піаніста Фердинанда Риса (1784-1838). За словами Мечислава Томашевського, ця тема здалася Шопенові настільки приємною, що в нього виникло бажання «зрівнятися з таким майстром, яким вважався Фердинанд Рис» ${ }^{9}$. (Зауважимо, що цю ж саму мелодію використав у своєму «Карнавалі у Венеції» Н. Паганіні).

Bapiaціï D-dur $є$ одним з перших шопенівських варіаційних циклів (нагадаємо, що автору в 1826 р. було лише 16 років). Втім питання про датування цього твору ще досі не вирішене остаточно. Так, 1826 рік як час написання цього циклу вказує сестра Шопена Людвіка Снджеєвич у своєму списку творів брата, упорядкованому в 1854 р., через п’ять років

\footnotetext{
${ }^{5}$ Там само, с. 195.

${ }_{7}^{6}$ Ивашкевич Я. Шопен. Москва : Молодая гвардия, 1963. С. 296.

7 Сорокина Е. Фортепианный дуэт: История жанра: Исследование. Москва : Музыка, 1988. C. $124-125$.

${ }^{8}$ Tomaszewski M. Cykl audycji "Fryderyka Chopina Dzieła Wszystkie”. Polish Radio, program II. URL: https://en.chopin.nifc.pl/chopin/composition/detail/id/11.

Там само. 
після смерті самого композитора та через 28 років після ймовірної дати створення Варіацій. Проте деякі музикознавці (І. Белза, Я. Екер) беруть це датування під сумнів, вважаючи, що варіації могли бути створені ще раніше, до $1826 \mathrm{p}$.

На думку I. Белзи, доказом більш раннього датування твору $\epsilon$, зокрема, те, що він помітно поступається за своїм художнім рівнем написаним у 1827 році (лише через рік, якщо прийняти наявну хронологічну атрибуцію) Варіаціям на тему «Дон Жуана» Моцарта ор. 2, у знаменитій рецензії на які Р. Шуман проголосив Шопена генієм. Утім, як підкреслює Белза, слід водночас відзначити позитивні якості чотириручних Варіацій D-dur: прагнення композитора до різноманітності фактури, яке наочно проступає, наприклад, у зіставленні «акордової ходи п’ятої варіації - Тетро di marcia - 3 «порхаючими» фігураціями заключного Vivace $<\ldots>$, і в хроматичній орієнтації пасажів» ${ }^{10}$.

У ранніх чотириручних варіаціях уже виявляються й деякі особливості ладогармонічного розвитку, притаманні зрілій шопенівській музичній мові. Так, наприклад, в основі гармонічної будови варіацій Ddur для фортепіано в чотири руки лежить медіантове зіставлення тональностей, яке згодом стає одним з улюблених шопенівських засобів музичної виразності.

Структура Варіацій є загалом типовою для Шопена: твір містить поряд 3 темою та п’ятьма варіаціями розгорнуту Інтродукцію та коду, які створюють, немов врівноважуючи одна одну, характерну архітектонічну арку, що надає творові гармонічної стрункості, цілісності та завершеності. Прагнення до єдності форми варіацій та цілісності художнього образу в усьому багатстві трансформацій теми виявляється й у створенні інтонаційно-тематичних «арок» між Інтродукцією та кодою, що також є притаманним для шопенівських варіацій та рондо варшавського періоду творчості.

Дуетне письмо Варіацій на тему Мура засноване на ієрархічному принципі підпорядкування партії Secondo, яка здебільшого виконує фонові, акомпануючі функції, партії Primo, що виконує провідну роль. Тож у системі дуетної комунікації цього твору інтегруюча ансамблева тенденція загалом переважає над діалогічною ${ }^{11}$. Фортепіанна фактура обох ансамблевих партій позначена рисами зрілого шопенівського піанізму, втіленими як на рівні мелодичної індивідуалізації блискучих пасажів, так i на рівні використання специфічних виконавських прийомів - перш за все аплікатурних (сковзання пальця з чорної клавіші

\footnotetext{
${ }^{10}$ Бэлза И. История польской музыкальной культуры: В 3-х томах. Москва : Музыка, 1972. Т. 3. C. 38 .

${ }^{11}$ Польская И.И. Камерный ансамбль: история, теория, эстетика : монография. Харьков : ХДАК, $2001.396 \mathrm{c}$.
} 
на білу, використання позиційних комплексів, зіставлень широкого та тісного розташування тощо).

Тож загалом Варіації на тему Т. Мура гідно репрезентують ранній етап творчості Шопена (попри те, що сам автор не вважав їх гідними публікації ${ }^{12}$ ). Вони вирізняються свіжістю, витонченістю, благородством та, безумовно, заслуговують на серйозну увагу сучасних виконавців $\mathrm{i}$ музикознавців.

Інший шопенівський фортепіанний ансамбль - Рондо C-dur для двох фортепіано, надруковане посмертно (1854) як ор. 73 - був написаний у 1828 р. (на думку деяких дослідників, можливо, ще у 1827 р.) ) $^{13}$ для сольного виконання на фортепіано (у дві руки). Дещо пізніше Рондо C-dur було перероблено автором для двофортепіанного дуету. Свідченням цього є два листи Шопена до Титуса Войцеховського від 9 вересня та від 27 грудня 1828 року. У першому 3 них Шопен, розповідаючи про переробку Рондо та про його можливе виконання, відзначає, що залишився задоволеним наслідками цієї праці (явище не дуже часте для надзвичайно вимогливого до себе композитора): «В Санніках я переробив Rondo C-dur (останнє, якщо пригадуєш) для двох фортепіано; сьогодні пробував його з Ернеманом у Бухгольца, i досить добре вдалося. Маємо намір якось заграти його в Купецькому зібранні Resursie» ${ }^{14}$. У другому листі він лише повідомляє про переробку та про те, що твір ще не опублікований: «9 вересня в Санніках у Прушаків я переробив для двох фортепіано Rondo C-dur (до сих пір ще не видане)» 15 .

Проблема датування Рондо дещо ускладнюється через певну двозначність тексту першого 3 процитованих шопенівських листів, пов'язану 3 фразою «Rondo C-dur (останнє, якщо пригадуєш)» ${ }^{16}$, що допускає можливість різної атрибуції саме цього твору, а не іншого рондо, написаного раніше (наприклад, рондо ор. 16, що його звичайно датують 1832 роком, хоча ця дата, за словами І. Белзи, не має ніякого документального підтвердження ${ }^{17}$ ).

Крім того, на нашу думку, саме про двофортепіанне Рондо C-dur ідеться у другому згаданому листі, де Шопен пише: «Осиротіле рондо C-dur для двох панталеонів знайшло в особі Фонтани свого вітчима $<\ldots>$. Він вивчав його більш як місяць, нарешті все ж вивчив, і недавно у

\footnotetext{
${ }^{12}$ Tomaszewski M. Cykl audycji "Fryderyka Chopina Dzieła Wszystkie”. Polish Radio, program II. URL: https://en.chopin.nifc.pl/chopin/composition/detail/id/11. C. 34.

Бэлза И. История польской музыкальной культуры: В 3-х томах. Москва : Музыка, 1972. Т. 3.

${ }^{14}$ Шопен Ф. Письма: В 2-х томах / Сост., вступ. ст., коммент, хронограф Г.С. Кухарского. 4-е изд. Москва : Музыка, 1989. Т. 1. С. 104.

15 Tам само, с. 113.

16 Там само, с. 104. C. 200.

17 Бэлза И. История польской музыкальной культуры: В 3-х томах. Москва : Музыка, 1972. Т. 3. 
Бухгольца ми переконалися в ефекті, який воно могло би зробити. Могло би тому, що не зовсім добре були настроєні панталеони, не завжди дописувало почуття (czucie) і всі ті дрібниці, котрі, як знаєш, надають стільки відтінків кожній речі» ${ }^{18}$. Доказами того, що тут ідеться не про панталеон як особливий струнно-молоточковий інструмент, а саме про фортепіано, на різновиди якого ця назва перейшла у XVIII сторіччі, $\epsilon$, на наш погляд, таке: 1) як підкреслює у своєму коментарі до одного 3 листів композитора до Яна Бялоблоцького (№ 22) Г. Кухарський, «Ф. Шопен часто вживає цю назву для позначення фортепіано» $\left.{ }^{19} ; 2\right)$ на користь такого припущення говорить зіставлення обставин можливого виконання Рондо C-dur та згаданого Рондо для двох панталеонів (місця, часу, імен виконавців, ситуації, що склалася), в т. ч. згадка у коментарі до листа про те, що «Ф. Шопен грав рондо 3 М. Ернеманом, який, мабуть, від'їхав; його замінив Ю. Фонтана» ${ }^{20}$.

Рондо C-dur op. 73 поєднує риси жанрового стереотипу бравурних салонних віртуозних творів із пошуками у сфері романтичної музичної форми, національного характеру тематизму, а також (що є особливо суттєвим) 3 формуванням індивідуальної композиторської манери письма та втіленого у ній неповторного піаністичного стилю.

Твір, написаний у формі тритемного рондо із розгорнутим вступом, поєднує у собі риси рондальності та сонатності. Величезну роль у розвитку музичного матеріалу Рондо C-dur відіграє, як і завжди у Шопена, варіаційність, що є основним принципом розробки тематизму. Ефектно-віртуозне начало втілено автором перш за все у музиці елегантної та блискучої першої теми рондо (mezza voce, leggiermente e scherzando) - рефрену (C-dur), що являє собою витончений синтез «діамантності», скерцозності та танцювальності. Характер теми політний, ефірний, «такий, що пурхає», з елементами легкого гумору. Музика рефрену хоча й позначена ще певним відбитком гуммелівської манери, але вже, безсумнівно, з виразним домінуванням шопенівської індивідуальності. Своєрідною є поява наприкінці рефрену (у першому та другому його проведеннях) нової теми (a-moll, потім е-moll) схвильовано-експресивної (con spirito), аріозно-декламаційної, 3 елементами трагедійної маршевості. Ця тема виникає як підсумкове завершення музичного розвитку рефрену і може розглядатися як його контрастне доповнення, що виконує роль своєрідної «сполучної партії». Особливу увагу привертає до себе надзвичайно виразна третя («побічна») тема Рондо (a-moll) - пісенно-романсового складу, лірична, 3 відтінком колисковості, яка створює глибокий емоційний контраст 3

\footnotetext{
${ }^{18}$ Шопен Ф. Письма: В 2-х томах / Сост., вступ. ст., коммент, хронограф Г.С. Кухарского. 4-е изд. Москва : Музыка, 1989. Т. 1. С. 112.

19 Там само, с. 80.

20 Там само, с. 113.
} 
усім попереднім тематизмом. Інтонаційний склад та емоційний характер цієї теми, безсумнівно, беруть своє походження від слов'янської лірикопротяжної пісенності. Водночас генеза згаданої теми, на нашу думку, може бути пов'язана 3 інтонаційною сферою ранньоромантичної романсової лірики. Ця тема відзначається особливою задушевністю, простотою та сердечністю, щирістю. Саме тут повністю вступає в свої права варіаційне начало - перш за все фактурно-підголоскового типу. У своїй другій появі (у «репризі» Рондо) вона звучить у медіантовій тональності e-moll, з'являючись на гребені драматичного розвитку рефрену та аріозно-декламаційної другої теми. Подальший розвиток музики рондо на рівні «дзеркальної репризи» форми - проведення «побічної» та «головної» (рефрен) тем - пов'язане зі значною образноемоційною та фактурною динамізацією матеріалу, посиленням конфліктного, драматичного, часом явно театрального начала, максималізацією образних контрастів, майже бетховенськими бурхливими динамічними зіткненнями образних сфер, ефектними зіставленнями кульмінацій $f f$ и $f f f$, які нагнітають напругу, та раптових прозорих piano. Невеличка кода грунтується на колосальному нагнітанні динаміки (від piano до $f f, f f f, s f f$ - sempre piu cresc.) та темпу (con molto fuoco e sempre accelerando sin'al fine). Тут найбільшою мірою дається взнаки вплив бравурно-віртуозних стереотипів, підміна справжнього драматизму його перебільшеною театралізованою імітацією, афектацією, яка так невластива зрілому шопенівському стилю. Загалом усі теми Рондо, незважаючи на контраст, мають певну спорідненість, яка більш за все відбивається на гармонічному рівні та на рівні фактури акомпанементу.

Ансамблеве письмо Рондо C-dur позначене високим ступенем діалогізації. Активну роль у ньому відіграє партія Secondo. Значна частина тематичного матеріалу або надходить до неї задля подальшого розвитку одразу ж після появи у партії Primo, або репрезентована виключно у Secondo. Композитор доручає їй не лише розгорнуті тематичні «відповіді» партії Primo, але й драматургічно важливі самостійні проведення музичного матеріалу. Саме таким $\epsilon$, наприклад, проведення драматичної, насиченої глибоким почуттям другої («сполучної») теми Рондо з ії довгою, «нескінченою» мелодією, або ж гранично театралізованого акордового передікту (marcato forte) до репризи ліричної пісенної теми рондо, що інтонаційно готує ії появу.

Таким чином, можна впевнено говорити про справді діалогічну взаємодію обох фортепіанних партій Рондо та про яскраве втілення у шопенівськім дуетнім письмі принципів ансамблевої рівноправності.

Піанізм Рондо позначений рисами зрілого шопенівського виконавського стилю. Активно застосовуються, наприклад, такі 
улюблені великим піаністом аплікатурні прийоми, як постійне використання широких позиційних комплексів у пасажах (тт. 75-76а, 79-80a, 137ab, 140-141ab, 367-368a, 389-392a) та мелодичних побудовах, вільне вживання першого пальцю на чорних клавішах (тт. 135ab, 139ab, 390a); мелодичне сковзання пальців (насамперед першого та п’ятого) як 3 чорної клавіші на білу (тт. 128а, 170а, 181-184a), так і по двох сусідніх білих клавішах (тт. 81a, 246a); «барокове» перехрещення та перекладення пальців (третього через четвертий (тт. 229a, 231a), четвертого через п'ятий (тт. 233-235a, 242-243a), третього через п’ятий (т. 98a), другого через п'ятий (тт. 237a, 239a) та третього й четвертого через п'ятий (тт. 361b, 365-366b, 373-374b)); одночасне взяття двох нот одним пальцем (тт. 381-384a); використання того ж самого пальця на різних клавішах $з$ метою еквівалентності звучання (тт. 361b, 369b); беззвучна легатна підміна пальців (тт. 81-82a, 84a, 86a); часта зміна широкого та тісного розташування пальців у пасажах (тт. 146b, 148b) із вживанням послідувань п'ятого та першого пальців.

3 огляду на вищевикладене категоричні заперечення викликає негативна оцінка цього шопенівського рондо Ю. Кремльовим, який вважає його лише «навчальним твором» 21 , кажучи, що «у цій розгорненій п'єсі появляються марковані народні ритми та мотиви, але багатослів'я пасажів діє надто пригнічуючи» ${ }^{22}$. На противагу цьому I. Белза, характеризуючи Рондо ор. 73 та інші юнацькі твори композитора у цьому жанрі (Рондо c-moll op. 1, Рондо F-dur op. 5, Grand Rondeau de Concert à la Krakowiak op. 14), підкреслює їхнє художне значення та історичну роль: «Створені у Варшаві рондо Шопена, безсумнівно, треба розглядати як ранній, але важливий етап становлення польської музичної класики» ${ }^{23}$. Таку думку цілком поділяє й авторка цієї статті.

\section{2. Фортепіанний ансамбль у виконавській діяльності Ф. Шопена}

Фортепіанне ансамблеве виконавство було дуже близьким Шопенові і у зрілі роки життя. Багато уславлених піаністів-віртуозів у 20-40-х роках XIX сторіччя часом об'єднувалися заради спільного концертування. У листах Шопена $\epsilon$ чимало згадок про вечори, «де буде увесь музичний світ і увертюра на вісім рук» ${ }^{24}$. Ф. Шопен у 30 -ті роки XIX ст. активно «концертував у ансамблі 3 багатьма популярними артистами Ф. Лістом, А. Герцом, Дж. Осборном, Т. Дельором, Й.П. Піксісом, C. 332 .

${ }^{21}$ Кремлев Ю. Фридерик Шопен: Очерк жизни и творчества. Изд. 3-е. Москва : Музыка, 1971.

${ }^{22}$ Там само, с. 332. C. 34 .

23 Бэлза И. История польской музыкальной культуры: В 3-х томах. Т. 3. Москва : Музыка, 1972.

${ }^{24}$ Шопен. Письма: В 2-х томах / Сост., вступ. ст., коммент, хронограф Г.С. Кухарского. 4-е изд. Москва : Музыка, 1989. Т. 1. С. 193. 
К. Черні, С. Тальбергом, Ф. Калькбреннером, Ф. Гіллером, К. Стаматі та ін.» ${ }^{25}-3$ виконанням не лише дуетних творів (для двох фортепіано або для фортепіано у чотири руки), але й творів, призначених для ансамблю трьох, чотирьох та більше фортепіано.

Саме 3 концерту, у програму якого входив написаний Ф. Калькбреннером спеціально з цієї нагоди «Великий полонез, якому передують інтродукція та марш» для шести фортепіано, розпочався паризький період концертного життя Шопена. Цей перший паризький публічний виступ польського музиканта відбувся 26 лютого 1832 року. У виконанні Великого полонезу поряд із Ф. Калькбреннером та Ф. Шопеном взяли участь відомі піаністи Ф. Гіллер, Дж. Осборн, К. Стаматі та В. Совінський.

Слід зазначити, що створення та виконання «Великого полонезу» Ф. Калькбреннера $є$ не лише цікавим фактом історії виконавського мистецтва та історії музики, а й має неабияке значення в органологічному сенсі як рідкісний зразок ансамблю для трьох різних типів фортепіано. При цьому характер інструментів та їх розподіл між виконавцями яскраво відбиває ієрархію артистичної вагомості названих музикантів та їх популярності на момент написання твору (в усякому разі з точки зору його автора).

Ф. Шопен у листі до свого друга Титуса Войцеховського від 12 грудня 1831 р. надає яскраву характеристику інструментів, необхідних для виконання ансамблевих партій у «Великому полонезі», та призначених кожному 3 них виконавських ролей: «Крім того, я граю 3 Калькбреннером на двох фортепіано, з акомпанементом чотирьох інших, його Mapu, suivie d'une Polonaise (супроводжуваний полонезом). Це шалена ідея. Один з інструментів - величезний пантелеон - призначений для Калькбреннера, другий, маленький, монохордний, але дзвінкий як дзвіночок, жирафик призначений для мене, а решта чотири сильні, мов оркестр. На них будуть грати Гіллер, Осборн, Стаматі та Совінський» 26. Тож очевидно, що самий вибір подібного інструментального складу сприяв, окрім усього іншого, досягненню позамузичної мети, пов'язаної 3 питаннями творчого престижу: підкреслювалися водночас масштаб мистецької особистості Ф. Калькбреннера порівняно з усіма іншими музикантами, певне сприяння автора твору його юному протеже Ф. Шопену, а також приблизна художньо-виконавська рівність чотирьох інших піаністів.

У паризький період життя Ф. Шопен багато виступав у фортепіанному ансамблі з різними відомими музикантами. Разом із Дж. Осборном,

\footnotetext{
${ }^{25}$ Польская И.И. Камерный ансамбль: история, теория, эстетика : монография. Харьков : ХДАК, 2001. C. 136.

${ }^{26}$ Шопен. Письма: В 2-х томах / Сост., вступ. ст., коммент, хронограф Г.С. Кухарского. 4-е изд. Москва : Музыка, 1989. Т. 1. С. 239. 
К. Стаматі та Й. Піксісом він взяв участь у виконанні ще одного ансамблевого твору Ф. Калькбреннера - п'єси для чотирьох фортепіано $^{27} .25$ лютого 1835 р. Шопен грає разом із Ф. Гіллером його Дует для двох фортепіано у залі Ерара ${ }^{28}$. Весною 1835 р. він разом із братами Герцами, Дж. Осборном та К. Стаматі виступає в «останньому концерті сезону» ${ }^{29}$. У грудні 1835 р. Шопен разом з В. Совінським грає вечорами під час Польського благодійного базару. 5 березня 1838 р. Шопен у ансамблі $з$ Ш. Альканом, П. Ціммерманом та А. Гутманом виконує восьмиручний фортепіанний переклад Анданте та фіналу симфонії Бетховена A-dur ${ }^{30} .29$ жовтня 1839 р. відбувся спільний концерт Ф. Шопена та I. Мошелеса у королівській резиденції в Сен-Клу, де в їх виконанні, зокрема, прозвучала Велика соната Мошелеса для фортепіано в чотири руки. "Revue et Gazette Musicale de Paris" 31 жовтня 1839 р. писала про цю подію таке: «Минулого вівторка король запросив пп. Мошелеса та Шопена в Сен-Клу, і ці два великі артисти грали перед двором $<\ldots>$. Велика Соната в чотири руки Мошелеса зробила таке враження, що королева побажала повторно послухати іiі Анданте <...> Ці два великі артисти прикували до себе увагу і поділяли захоплення двору протягом усього вечора ${ }^{31}$. Також разом із композитором, піаністом і музикознавцем Ж.-А. де Меро (майбутнім головою Руанської Академії наук, літератури і мистецтва) Шопен зіграв фортепіанний дует цього митця на теми $з$ опери «Пре-о-Клер» Л. Герольда ${ }^{32}$.

Найбільш тривалим та плідним виявився ансамбль Ф. Шопена із Ф. Лістом. Два великі музиканти протягом низки років багаторазово виступали разом як у дуеті, так $\mathrm{i}$ в інших видах фортепіанного ансамблю. Так, у квітні 1833 р. Шопен та Ліст разом із братами Анрі та Жаком Герцами грали у їхньому концерті квартет у вісім рук на двох фортепіано $^{33}$, а також виступали у концерті-бенефісі уславленої англійської актриси Гаррієт Смітсон - коханої, а потім дружини Г. Берліоза, героїні його «Фантастичної симфонії» ${ }^{34} 15$ грудня 1833 p. вони взяли участь у концерті Ф. Гіллера, що відбувся у залі консерваторії, виконавши разом 3 ним Allegro 3 концерту d-moll для трьох клавірів Й.С. Баха ${ }^{35}$. У рецензії Ф. Фетіса на цей концерт у "Revue Musicale" від 21 грудня 1833 р. підкреслювалося, що «фрагмент для трьох фортепіано, виконаний панами Гіллером, Лістом і Шопеном,

\footnotetext{
27 Зингер Е. Из истории фортепианного искусства Франции. Москва : Музыка, 1976. С. 43.

${ }^{28}$ Шопен Ф. Письма: В 2-х томах / Сост., вступ. ст., коммент, хронограф Г.С. Кухарского. 4-е изд. Москва : Музыка, 1989. Т. 1. С. 39.

${ }_{29}^{29}$ Там само, с. 43.

${ }^{30}$ Там само, с. 43.

31 Там само, с. 44

32 Зингер Е. Из истории фортепианного искусства Франции. Москва : Музыка, 1976. С. 100.

${ }^{33}$ Шопен Ф. Письма: В 2-х томах / Сост., вступ. ст., коммент, хронограф Г.С. Кухарского. 4-е изд. Москва : Музыка, 1989. Т. 1. С. 37.

${ }^{34}$ Там само, с. 37.

35 Там само, с. 38.
} 
приніс нам рідкісне задоволення: три артисти виконали цей уривок скажемо відверто - вишукано, 3 досконалим проникненням у його характер» ${ }^{36}$. 25 грудня 1834 р. обидва великі піаністи виконали у денному концерті-бенефісі відомого німецького педагога Ф. Штепеля у залі Плейєля Дует I. Мошелеса для фортепіано в чотири руки та Фантазію-дует Ф. Ліста для двох фортепіано на тему однієї 3 пісень Ф. Мендельсона ${ }^{37}$. (Останній 3 цих творів, як відзначає А. Соловцов, скоріш за все, не зберігся) ${ }^{38}$. Враження від виступу «зоряного дуету» було надзвичайно великим. Паризька "Gazette musicale" із захопленням писала 28 грудня 1834 р.: «Панове Ліст і Шопен блискуче відкрили його концерт Великим дуетом для фортепіано в чотири руки Мошелеса. Нам видається зайвим говорити, що п'єса - один із шедеврів композитора була виконана 3 рідкісною досконалістю талантів двома найбільшими віртуозами нашої епохи» ${ }^{39}$. Саме після цього концерту газета назвала Шопена та Ліста «найвеличнішими піаністами епохи» ${ }^{40}$ та особливо відзначила «ентузіастичний прийом» ${ }^{41}$ публіки.

У квітні 1835 р. Шопен організує на користь польських емігрантів концерт в Італійському театрі, у програмі якого серед інших творів грає разом 3 Лістом Дует Гіллера для двох фортепіано ${ }^{42} .9$ квітня 1836 р. Шопен та Ліст виконали у концерті останнього у залі Ерара - на завершення програми - Лістівський віртуозний «Великий бравурний вальс» для фортепіано у чотири руки ${ }^{43}$. Цей же твір вони також зіграли разом якраз через рік - 9 квітня 1837 р. - у тому ж самому залі Ерара ${ }^{44}$. Спільне виконання Лістом та Шопеном під час одного з музичних вечорів на квартирі Шопена, що відбувся у 1836 р., ще одного монументального твору - Сонати I. Мошелеса для фортепіано у чотири руки (партія Primo - Ф. Ліст, партія Secondo - Ф. Шопен) - описує, зокрема, у своїх спогадах польський віолончеліст, композитор та диригент Ю. Бжовський ${ }^{45}$. Відомо також, що в останній період свого життя - під час концертного турне по Англії - Ф. Шопен, виступаючи 15 травня 1848 р. у домі у герцогині Сазерленд, серед інших творів зіграв (разом із Юл. Бенедиктом) варіації G-dur (KV 501) В.А. Моцарта для фортепіано в чотири руки ${ }^{46}$.

\footnotetext{
36 Там само, с. 38 .

${ }^{37}$ Там само, с. 39.

${ }^{38}$ Соловцов А. Фридерик Шопен: Жизнь и творчество. Москва : Музгиз, 1960. С. 116.

${ }^{39}$ Шопен Ф. Письма: В 2-х томах / Сост., вступ. ст., коммент, хронограф Г С. Кухарского. 4-е изд. Москва : Музыка, 1989. Т. 1. С. 39.

${ }_{40}$ Соловцов А. Фридерик Шопен: Жизнь и творчество. Москва : Музгиз, 1960. С. 116.

41 Там само, с. 116.

42 Шопен Ф. Письма: В 2-х томах / Сост., вступ. ст., коммент, хронограф Г. С. Кухарского. 4-е изд. Москва : Музыка, 1989. Т. 1. С. 40.

${ }^{43}$ Там само, с. 40-41.

44 Там само, с. 41.

45 Соловцов А. Фридерик Шопен: Жизнь и творчество. Москва : Музгиз, 1960. С. 122-124.

${ }^{46}$ Шопен Ф. Письма: В 2-х томах / Сост., вступ. ст., коммент, хронограф Г.С. Кухарского. 4-е изд. Москва: Музыка, 1989. Т. 1. С. 51; Шопен Ф. Письма: В 2-х томах / Сост., авт. коммент, сост. указателей Г.С. Кухарского.. 2-е изд., доп. Москва : Музыка, 1980. Т. 2: Переводы. С. 216.
} 
Певною мірою можна вважати ансамблевим і виконання Ф. Шопеном (разом із його геніально обдарованим юним учнем Карлом Фільчом) одного зі своїх фортепіанних концертів на двох фортепіано, що відбулося на вечорі у Дж. Ротшильда 20 січня 1843 р., де виступали всі славнозвісні артисти Парижа ${ }^{47}$.

Слід також підкреслити, що фортепіанні ансамблеві твори були невід'ємною частиною шопенівського педагогічного репертуару. Чільне місце серед них посідали, зокрема, шубертівські фортепіанні чотириручні дуети - полонези, марші, лендлери, «Угорський дивертисмент» ${ }^{48}$. Про їх вивчення під наставництвом Ф. Шопена згадувала, зокрема, Каміла Дюбуа - одна 3 найобдарованіших учениць великого польського музиканта, професійна піаністка, яка стала згодом відомим паризьким фортепіанним педагогом ${ }^{49}$.

\section{3. Камерно-інструментальна ансамблева творчість Ф. Шопена (композиторська та виконавська)}

Окрім гри в різноманітних фортепіанних ансамблях, Шопен нерідко виступав у камерно-інструментальних ансамблевих складах (дуетах, тріо), насамперед за участю віолончелі. Його творча спадщина містить кілька камерно-інструментальних творів, перш за все для віолончелі 3 фортепіано.

Ще у юнацькі роки Шопен пише свої перші камерно-ансамблеві твори - віолончельні п'єси (Інтродукцію та Полонез ор. 3), Тріо для фортепіано, скрипки та віолончелі ор. 8 - та сам бере участь у їх виконанні ${ }^{50}$

Полонез C-dur op. 3 для фортепіано i віолончелі, присвячений уславленому віденському віолончелісту Й. Мерку, був створений Шопеном восени 1829 р. у домі князя А. Радзивілла у маєтку Антонін поблизу Каліша, де Шопен гостював протягом тижня (з 29 жовтня по 6 листопада 1829 р. $)^{51}$. Саме там цей твір був одразу же вперше виконаний ${ }^{52}$. Шопен із притаманним йому легким гумором повідомляв про написання цього твору Титуса Войцеховського: «Я написав у нього (Радзивілла - I.П.) alla polacca 3 віолончеллю. В ньому лише блискучі дрібнички для салону, для дам, мені, бачиш, хотілося, щоби його вивчила к(няж)на Ванда» ${ }^{53}$. Пізніше до Полонезу була дописана Інтродукція - Adagio - спеціально для відомого варшавського

\footnotetext{
${ }^{47}$ Шопен Ф. Письма: В 2-х томах / Сост., вступ. ст., коммент, хронограф Г.С. Кухарского. 4-е изд. Москва : Музыка, 1989. Т. 1. С. 47.

${ }^{48}$ Николаев В. А. Шопен - педагог. Москва : Музыка, 1980. С. 30-31.

${ }^{49}$ Там само, с. $34,36$.

${ }^{50}$ Шопен Ф. Письма: В 2-х томах / Сост., вступ. ст., коммент, хронограф Г.С. Кухарского. 4-е изд. Москва : Музыка, 1989. Т. 1. С. 33-34.

${ }^{51}$ Там само, с. 33.

52 Там само, с. 34 .

${ }^{53}$ Там само, с. 141.
} 
віолончеліста Ю. Качинського ${ }^{54}$. Полонез разом 3 Інтродукцією вперше був виконаний дуетом Качинський-Шопен під час музичного вечора у Левицьких, де цим твором завершилася концертна програма. Про новий варіант твору Шопен стисло пише Войцеховському: «Ми його вже пробували - може бути» ${ }^{55}$.

Дослідники творчості Шопена неодноразово дорікали композиторові за ансамблеве письмо Полонезу, у якому віртуозна й блискуча фортепіанна партія панує над віолончельною. Втім важко уявити, щоб Шопен 3 його надзвичайним відчуттям гармонії, міри, пропорційності міг так собі захопитися фортепіанною фактурою та не розрахувати тут баланс ансамблевих партій. Скоріше інше.

Згадаємо про те, що у бароковій та класицистичній традиції був дуже поширений жанр творів для клавесину (фортепіано) з акомпанементом скрипки або віолончелі і що ще на початку XIX сторіччя створювалися сонати для фортепіано у супроводі скрипки або віолончелі (яскравим прикладом цього $\epsilon$ авторські ремарки скрипкових сонат Бетховена) ${ }^{56}$. Тож можна з великою ймовірністю припустити, що Шопен у такому разі свідомо віддає данину наявній класицистській традиції, зважаючи одночасно на мистецькі орієнтації мимовільного «винуватця» появи Полонезу для віолончелі та фортепіано - князя Радзивілла, який був, між іншим, як відзначає Я. Івашкевич, автором першої та єдиної музики до «Фауста», що її схвалив сам Й.В. Гете ${ }^{57}$.

Тож важко погодитися з оцінкою Полонеза Ю. Кремльовим: «Для нас він (Полонез. - І.П.) цікавий передусім стосовно розвитку фортепіанної фактури і техніки: широких регістрових відстаней, «обігрувань» у пасажах, ланцюгів зменшених септакордів і паралельних хроматичних секстакордів тощо» ${ }^{58}$. Безумовно, своєрідне шопенівське вирішення фактурних проблем $\epsilon$ важливим для вивчення еволюції його піаністичного стилю, однак музика Полонезу приваблює виконавців аж ніяк не лише 3 цього погляду. Вона $\epsilon$ цікавою також в аспекті трактування самого жанру, мелодико-гармонічного складу твору, розвитку тематичного матеріалу, специфіки ансамблевого діалогу.

Оцінюючи Полонез, можна, мабуть, багато в чому погодитися із думкою А. Соловцова про те, що «за мистецькими вартостями він, безумовно, поступається тріо. < ..> Звичайно, «нісенітницею» не можна назвати і цей твір. Смак, витончене знання засобів фортепіано (i тут

\footnotetext{
${ }^{54}$ Шопен Ф. Письма: В 2-х томах / Сост., вступ. ст., коммент, хронограф Г.С. Кухарского. 4-е изд. Москва : Музыка, 1989. Т. 1. С. 143.

${ }_{55}^{5}$ Там само, с. 148.

${ }^{56}$ Кириллина Л. Сонатный цикл и сонатная форма в представлениях Бетховена. Музыкальный языюк, жанр, стиль : сб. науч. трудов. Москва : Москов. Гос. консерватория им. П.И. Чайковского, 1987. C. 98 .

${ }_{57}^{5 в}$ Ивашкевич Я. Шопен. Москва : Молодая гвардия, 1963. С. 84. C. 335 .

${ }^{8}$ Кремлев Ю. Фридерик Шопен: Очерк жизни и творчества.. Изд. 3-е. Москва : Музыка, 1971. 
провідна роль належить цьому інструментові) не зрадили Шопену. Багато, безсумнівно, «шопенівського» у фортепіанному письмі полонезу. Але загалом цей твір не належить до числа характерних для його автора» ${ }^{59}$. Справді, Полонез важко назвати одним 3 найвищих досягнень шопенівського генія, однак цей блискучий ефектний твір $\epsilon$ яскравим зразком віртуозно-концертного напряму у шопенівській камерно-інструментальній творчості, багато у чому етапним на творчому шляху автора.

Створення i перше виконання Тріо для фортепіано, скрипки та віолончелі g-moll op. 8 також відбулося у маєтку князя А. Радзивілла восени $1829 \mathrm{p}^{60}$. Цей ранній шопенівський твір уперше був опублікований (з присвятою А. Радзивіллу) у березні 1833 р. у Парижі ${ }^{61}$.

Зазначимо, що 3 приводу цього Тріо деякі музикознавці (зокрема, Г. Ляйхтентрітт) висловлювали припущення про слабке знання Шопеном можливостей скрипки, наслідком чого стало використання лише найпростіших скрипкових виконавських прийомів ${ }^{62}$. Але доволі переконливим видається спростування згаданої тези, котре наводить I. Белза: «Версія про «недостатнє знання» струнних інструментів видається цілковито непереконливою хоч би тому, що Шопен <..> чудово знав музичну літературу, включаючи численні камерноінструментальні ансамблі, які часто виконувалися в домі його батька. Про рівень його знань досить переконливо свідчить їх практичне застосування в тих творах Шопена для фортепіано з оркестром, котрі були створені ще до тріo g-moll. Просто і в цьому разі проявилися новаторські поривання Шопена, що позначилися як на трактовці струнних інструментів, так і на принципах композиції ансамблю в цілому» $^{63}$. Можливо, слід також погодитися 3 думкою того ж І. Белзи про те, що «характер партій скрипки та віолончелі» був зумовлений саме кантиленністю, яка домінує у тріо, і притаманною шопенівській музиці виразною співучастю та пластичністю мелодики ${ }^{64}$.

У музиці тріо домінують життєрадісні, оптимістичні тони. Суттєву роль у цьому відіграє, зокрема, танцювальне начало. Однак уже в цьому юнацькому творі (особливо у повільній частині - Adagio sostenuto) помітні характерні для зрілої шопенівської творчості драматизм, глибина та сила емоційного переживання, яка часом підноситься до рівня високої патетики. Це створює значний образно-емоційний контраст між музикою різних частин тріо. Як відзначає А. Соловцов,

\footnotetext{
${ }^{59}$ Соловцов А. Фридерик Шопен: Жизнь и творчество. Москва : Музгиз, 1960. С. 326-327.

${ }^{60}$ Там само, с. 33.

${ }^{61}$ Там само, с. 37.

${ }^{62}$ Leichtentritt Hugo. Friedrich Chopin. Berlin : Harmonie Verlag, 1920. S. 34.

${ }_{63}^{63}$ Бэлза И. История польской музыкальной культуры: В 3-х томах. Т. 3. Москва : Музыка, 1972. C. 49 .

${ }^{64}$ Там само, с. 49.
} 
«схвильованість Allegro контрастує з вишуканістю наступного скерцо, в якому нема й натяку на драматичні бурі фортепіанних скерцо. Патетична лірика Adagio змінюється невимушеними веселощами фіналу (головна тема фіналу споріднена 3 першою темою фіналу e-moll'ного концерту і також виросла з ритмів краков'яку)» ${ }^{65}$.

Надзвичайно високо оцінював шопенівське Tpio g-moll Роберт Шуман. Він відзначав, що хоча цей твір був створений у початковий період творчості Шопена, «коли він ще надавав деяку перевагу віртуозності» $^{66}$, та це насамперед має відношення до «повнозвучної $\mathrm{i}$ блискучої фортепіанної партії, якій Шопен визначив у своєму ансамблі ведучу роль» ${ }^{67}$. Шуман особливо підкреслював, що «Шопен уже пройшов різні стадії свого розвитку, найважче стало для нього дитячою забавою, і він уже відкидає це i, як справді мистецька натура, віддає перевагу простішому» ${ }^{68}$. Він захоплено писав у рецензії: «Що я можу сказати про це тріо, чого не сказав би собі кожний, здатний його відчути? Хіба воно не є благородним настільки, наскільки це взагалі можливо, не є замріяним так, як ще жоден поет не співав, не $є$ своєрідним від кожної дрібниці до цілого, хіба кожна його нота - не музика, не саме життя?» ${ }^{69}$.

Зауважимо, що саме твори за участю віолончелі є єдиними 3 «позафортепіанних», «іншоінструментальних» ансамблів, які неодноразово трапляються у шопенівському доробку у різні періоди життєтворчості митця.

Так, упродовж багатьох років тривала творча (виконавська та композиторська) співдружність Шопена із видатним віолончелістом, професором Паризької консерваторії Огюстом Франкоммом, якому присвячений останній шопенівський твір, опублікований за життя автора - Соната g-moll для віолончелі та фортепіано ор. 65 (1846, вид. 1847). Цей твір та написаний у співавторстві «Великий концертний дует на теми 3 опери Дж. Мейєрбера «Роберт-Диявол» обидва музиканти неодноразово з великим успіхом виконували разом, у тому числі на музичних вечорах у домі Шопена ${ }^{70}$. Соната g-moll для віолончелі та фортепіано ор. 65 входила і до програми останнього паризького концерту у залі Плейєля 16 лютого 1848 року (виконавці - Ф. Шопен та О. Франкомм). У цім концерті прозвучав ще один камерно-ансамблевий

\footnotetext{
${ }^{65}$ Соловцов А. Фридерик Шопен: Жизнь и творчество. Москва : Музгиз, 1960. С. 326.

66 Шуман Р. О музыке и музыкантах: Собрание статей в двух томах / Сост., ред., вступ. ст. и коммент. Д.В. Житомирского. Пер. с нем. А.Г. Габричевского и Л.С. Товалевой. Ред. перевода Г.А. Балтер. Т. 1. Москва : Музыка, 1975. С. 276.

67 Там само, c. 276.

${ }^{68}$ Там само, с. 276.

${ }^{69}$ Шуман Р. О музыке и музыкантах: Собрание статей в 2-х томах / Сост., ред., вступ. ст. и коммент. Д.В. Житомирского. Пер. с нем. А.Г. Габричевского и Л.С. Товалевой. Ред. перевода Г.А. Балтер. Москва : Музыка, 1975. Т. 1. С. 276.

${ }^{70}$ Шопен Ф. Письма: В 2-х томах / Сост., вступ. ст., коммент, хронограф Г.С. Кухарского. 4-е изд. Москва : Музыка, 1989. Т. 1. С. 49-50.
} 
твір - Тріо В.А. Моцарта, яке теж було чудово виконане Ф. Шопеном, О. Франкоммом та скрипалем Ж. Аларом ${ }^{71}$.

У захопленій рецензії на згаданий концерт, надрукованій у "La Gazette Musicale" від 20 лютого 1848 р., віолончельну сонату було названо шедевром. У статті відзначалося: «Легше розповісти про той прийом, який виявили йому, про той екстаз, який він збудив, ніж описати, проаналізувати, вивести на світло денне тайни виконання, якому нема рівного у нашій земній юдолі... Програма обіцяла, що першим номером буде виконано тріо Моцарта, яке було загране Шопеном, Аларом i Франкоммом з високою досконалістю, що не залишала жодних надій на те, що коли-небудь його зможуть так виконати. Потім Шопен грав свої етюди, прелюдії та вальси і, нарешті, з Франкоммом свою прекрасну сонату. Не запитуйте, як були виконані всі ці шедеври, маленькі та великі. <.. > Скажемо лише, що чари не залишали слухачів ні на мить i продовжували тривати ще й після закінчення концерту» ${ }^{72}$.

Над Віолончельною сонатою Шопен працював напружено та досить довго - 31845 по кінець 1846 р. Ще в грудні 1845 р. він писав рідним до Варшави: «Тепер я хотів би завершити сонату 3 віолончеллю» ${ }^{73}$. «Я трохи пробував 3 Франкоммом свою сонату з віолончеллю, йшло добре» ${ }^{74}$. Подібна оцінка твору в устах завжди винятково стриманого та вимогливого до себе Шопена є дуже високою. Але його ставлення до сонати у процесі роботи увесь час змінювалося, він постійно працював над iі вдосконаленням: «Своєю віолончельною сонатою я то задоволений, то ні. Кидаю іiі в кут, а потім знову беру <...>. Коли компонуєш, все видається добрим, - інакше нічого би не писалося. Тільки пізніше починаєш роздумувати - і тоді або відкидаєш, або приймаєш. Час - найкращий цензор, а терпіння - прекрасний вчитель» ${ }^{75}$ (3 листа до рідних у Варшаву від 11 жовтня 1846 р.).

Щодо оцінки художніх якостей Віолончельної сонати думки шопенознавців принципово розходяться. Одні (Ю. Кремльов, Ф. Нікс) вважають їі невдалим наслідком творчого експерименту, пов'язаного із пошуками композитором нових виразових засобів, нових стильових узагальнень на переломнім етапі творчого шляху. Інші (А. Соловцов, I. Белза, Й.М. Хомінський, Зд. Яхімецький), навпаки, визнають цю сонату одним з найзначніших шопенівських творів пізнього періоду, підкреслюючи цілу низку позитивних якостей, притаманних виключно ій. Так, А. Соловцов відзначає, що «соната для віолончелі та фортепіано (g-moll op. 65) значно відрізняється від інших пізніх шопенівських

\footnotetext{
${ }^{71}$ Там само, с. 50

${ }^{72}$ Шопен Ф. Письма: В 2-х томах / Сост., авт. коммент, сост. указателей Г.С. Кухарского. 2-е изд., доп. Москва : Музыка, 1980. Т. 2: Переводы. С. 197.

${ }_{73}$ Там само, с. 113.

${ }^{74}$ Там само, с. 113 .

${ }^{75}$ Там само, с. $134-135$.
} 
творів <..>. У віолончельній сонаті потрібно відзначити строгу простоту і благородство стилю, чудове знання засобів обох інструментів (у сонаті, на відміну від полонезу ор. 3, уже нема панування фортепіано над віолончеллю). За емоційним тоном віолончельна соната належить до драматичних опусів Шопена, хоча й не підноситься до трагічної сили сонати b-moll або фантазії» ${ }^{76}$. I. Белза слушно зазначає: «Навряд чи у всій романтичній літературі можна би назвати сонатний цикл, між усіма частинами якого тематичні зв'язки були би такими глибокими та міцними, як у віолончельній сонаті. I можна лише дивуватися, що ці зв'язки залишились непоміченими багатьма дослідниками, а соната, як зазначає Хомінський, - недооціненою» ${ }^{77}$. А Здзіслав Яхімецький підкреслює: «Тільки тепер ми можемо повною мірою оцінити історичне значення цієї сонати» ${ }^{78}$.

Величезне значення Віолончельної сонати у творчій спадщині Шопена та особливе ставлення композитора до неї підкреслює, зокрема, той факт, що за кілька днів до смерті він забажав послухати саме цей твір. Але цьому бажанню не судилося здійснитися через раптове погіршення стану здоров'я хворого. Як відзначає Соловцов, «не встигли Марцеліна Чарторийська i Франкомм заграти декілька тактів шопенівської віолончельної сонати, як приступ задушливого кашлю, що охопив хворого, заставив їх припинити гру» ${ }^{79}$.

Великий концертний дует для фортепіано та віолончелі на теми 3 опери Дж. Мейєрбера «Роберт-Диявол», написаний Ф Шопеном спільно iз О. Франкоммом у 1832 р., був надрукований наступного року. Цей дует, поступаючись, безумовно, за своїми художніми якостями Віолончельній сонаті, є водночас яскравою, ефектною п'єсою, яка гідно репрезентує риси шопенівського творчого почерку та піаністичного стилю. Як підкреслює Ю. Кремльов, музика дуету позначена «не лише винахідливістю фантазії, але й поезією думки, в якій оригінальний, напоєний фольклором дар Шопена раз-у-раз дається взнаки» ${ }^{80}$.

Партія фортепіано відзначається значною віртуозністю, ефектністю, художньою виразністю, блиском характерних шопенівських пасажів. Найвищого піднесення піанізм Дуету досягає в Інтродукції, яка являє собою своєрідний «бенефіс» фортепіанної партії. Втім, попри надто високу активність фортепіанної партії, ансамблеве письмо твору характеризується збалансованістю та гармонійністю виконавських ролей обох інструментів.

\footnotetext{
${ }_{77}^{76}$ Соловцов А. Фридерик Шопен: Жизнь и творчество. Москва : Музгиз, 1960. С. 326-327.

77 Бэлза И. История польской музыкальной культуры: В 3-х томах. Москва : Музыка, 1972. Т. 3. C. 165 .

${ }^{78}$ Jachimecki Zdz. Chopin: rys życia i twórczości. Krakow : Polskie Wydawn. Muzyczne, 1957. P. 279.

79 Соловцов А. Фридерик Шопен: Жизнь и творчество. Москва : Музгиз, 1960. С. 179. C. 385 .

${ }^{80}$ Кремлев Ю. Фридерик Шопен: Очерк жизни и творчества. Изд. 3-е. Москва : Музыка, 1971. 
Слід зазначити, що окрім фортепіанних дуетів, фортепіанного тріо та творів для віолончелі та фортепіано, шопенівська композиторська спадщина містить і звернення до флейти з фортепіано та (імовірно) скрипки з фортепіано.

Так, одним 3 юнацьких творів Шопена варшавського періоду творчості є Варіації на тему з опери Дж. Россіні «Попелюшка» (1827 або 1829 рр.), написані для флейти з акомпанементом фортепіано (вперше видані у 1953 р.). Проте $\epsilon$ думка, що ці Варіації, можливо, не $\epsilon$ цілком шопенівськими, а $є$ наслідком спільної праці різних авторів. Так, деякі дослідники шопенівської творчості (Я. Проснак, А. Соловцов) вважають малоймовірним, що досить примітивна за своїм змістом та фактурою фортепіанна партія варіацій, яка аж ніяк не відповідає «вишукановіртуозному стилю флейтової партії та стилю фортепіанних творів Шопена» ${ }^{81}$, належить перу Шопена. Якщо погодитися 3 версією польського музикознавця Я. Проснака про те, що акомпанемент був просто «приписаний» кимсь до флейтової партії ${ }^{82}$, то виникає питання, чи існував взагалі шопенівський текст фортепіанної партії, а якщо існував, то чи зберігся де-небудь його рукопис. На жаль, на ці питання відповідей поки що немає i, можливо, не буде зовсім.

Окреслюючи органологічні аспекти камерно-ансамблевої спадщини Ф. Шопена, слід зазначити також випадок його творчого звернення до жанру скрипкового дуету з фортепіано. Так, у 1830 р. Шопен у листах 3 Відня згадує про ще один ансамблевий задум, пов'язаний зі спільною працею $з$ геніальним чеським композитором та скрипалем Йозефом Славіком над створенням Варіацій для скрипки та фортепіано на тему Бетховена. У листі до рідних він пише: «Ми вирішили разом написати дует для скрипки і фортепіано - думка, котра виникла у мене у Варшаві» ${ }^{83}$. У листі до Яна Матушинського йдеться вже про практичне втілення цієї ідеї: «Я якраз повертався від Славіка <...>; у нього мені прийшла думка, повернувшись додому, потужити за фортепіано i виплакати adagio до варіацій на тему Бетховена, котрі ми разом з ним пишемо» ${ }^{84}$. На жаль, цей твір не дійшов до нашого часу, тому невідомо, чи він був завершений автором, чи залишився у ескізах ${ }^{85}$.

Підбиваючи підсумки аналізу камерно-ансамблевої творчості великого польського музиканта, важко погодитися 3 твердженнями деяких музикознавців про те, що «нечисленні камерні ансамблі Шопена не належать до числа його кращих і найбільш своєрідних творів» ${ }^{86}$.

\footnotetext{
${ }_{81}^{81}$ Соловцов А. Фридерик Шопен: Жизнь и творчество. Москва : Музгиз, 1960. С. 459.

${ }^{82}$ Prosnak J. Wariacje fletowe Chopina. Studia muzykologiczne. T. 1. Krakow : P.W.M., 1953. S. 267;

Соловцов А. Фридерик Шопен: Жизнь и творчество. Москва : Музгиз, 1960. С. 459.

${ }_{83}$ Шопен Ф. Письма: В 2-х томах / Сост., вступ. ст., коммент, хронограф Г.С. Кухарского. 4-е изд. Москва : Музыка, 1989. Т. 1. С. 193.

${ }_{84}^{84}$ Там само, c. 196.

${ }^{85}$ Там само, c. 201.

${ }^{86}$ Соловцов А. Фридерик Шопен: Жизнь и творчество. Москва : Музгиз, 1960. С. 326.
} 
(Зауважимо, що навіть ці дослідники визнають, що «творчу фізіономію Шопена легко впізнати і в камерно-інструментальних творах») $)^{87}$. Тож слід скоріше говорити про певну історичну несправедливість, що призвела до тривалої недооцінки камерно-інструментальної музики Шопена, перш за все таких видатних витворів його зрілого генія, як Віолончельна соната.

\section{ВИСНОВКИ}

Мистецька особистість Фридерика Шопена традиційно сприймається передусім крізь призму його піаністичної діяльності та фортепіанної творчості. Проте одним із важливих факторів творчої біографії Ф. Шопена $є$ також неодноразове звернення до сфери ансамблевого мистецтва, яке знайшло своє віддзеркалення в його виконавській діяльності та композиторській спадщині. Однак ансамблева творчість великого польського музиканта ще й досі, на жаль, належить до найменш досліджених напрямів його художнього доробку.

Основними напрямами ансамблевої творчості Шопена є фортепіанний і камерно-інструментальний ансамбль (насамперед для віолончелі та фортепіано). Фортепіанний ансамбль представлений у композиторській спадщині Шопена саме дуетними жанрами - творами для фортепіано в 4 руки (Варіації F-dur на власну тему, 1826, та Варіації D-dur на тему Т. Мура, 1826) та для двох фортепіано (Рондо C-dur op 73, 1828), написаними митцем виключно у варшавський період творчості. У концертно-виконавській діяльності великого польського піаніста, яка відбувалася більшою мірою в паризькій період його життя, широко представлені й інші види такого ансамблю (у 8 рук на двох фортепіано, а також на декількох - від 3 до 6 - різних фортепіано, у тому числі типологічно відмінних). Серед піаністів - партнерів Ф. Шопена по ансамблевому концертуванню - слід назвати імена таких уславлених музикантів, як Ф. Ліст, І. Мошелес, Ф. Калькбреннер, А. Герц, Ф. Гіллер, К. Черні, С. Тальберг, Й.П. Піксіс, Т. Дельор, К. Стаматі, П. Ціммерман, Ш. Алькан, Юл. Бенедикт та багато ін.

Суттєвим складником мистецької спадщини Ф. Шопена $\epsilon$ його камерно-інструментальна творчість. Композиторський доробок музиканта містить передусім твори за участю віолончелі (Інтродукція та Полонез для фортепіано і віолончелі ор. 3, 1829; Тріо для фортепіано, скрипки та віолончелі g-moll op. 8, 1829; Соната g-moll для віолончелі та фортепіано ор. 65,1846 , та написаний у співдружності із О. Франкоммом «Великий концертний дует на теми з опери Дж. Мейєрбера «РобертДиявол», 1832), а також юнацькі Варіації на тему з опери Дж. Россіні «Попелюшка» для флейти 3 фортепіано (1827 чи 1829). Є також

${ }^{87}$ Там само, с. 326. 
документальні свідчення про задум створення (разом із Й. Славіком) Варіацій для скрипки та фортепіано на тему Бетховена (1830), втім, невідомо, чи був він реалізований автором. Щодо камерно-ансамблевої виконавської діяльності Ф. Шопена, то головним його партнером у цій сфері протягом багатьох років був видатний французький віолончеліст О. Франкомм, серед інших слід назвати передусім відомих скрипалів Й. Славіка та Ж. Алара.

Підбиваючи підсумки аналізу ансамблевої творчості Ф. Шопена, слід зазначити, що з другої пол. ХХ ст. відбувається поступове відродження багатьох ансамблевих творів митця 3 тривалого небуття. Вершинні досягнення шопенівського генію в сфері фортепіанного та камерноінструментального ансамблю (насамперед Віолончельна соната, Рондо для двох фортепіано та Тріо для фортепіано, скрипки та віолончелі) прикрашають концертний репертуар багатьох виконавців-ансамблістів, використовуються у музично-педагогічній практиці, а також усе більше звертають на себе увагу науковців-дослідників.

\section{АНОТАЦІЯ}

Стаття присвячена дослідженню проблематики, пов'язаної із визначенням ролі фортепіанного та камерного ансамблю в житті та творчості Ф. Шопена. Об'єктом дослідження є композиторська i виконавська творчість Ф. Шопена, пов'язана зі сферами фортепіанного та камерного ансамблів. Визначається специфіка фортепіанного ансамблю й фортепіанного дуету як його провідного репрезентанту, жанровими типами якого є чотириручний фортепіанний дует на одному фортепіано та двофортепіанний дует. Підкреслено ексклюзивну роль саме фортепіанного дуету (в обох його іпостасях) у композиторській ансамблевій спадщині Шопена поряд із широкою репрезентацією інших різновидів фортепіанного ансамблю у виконавській діяльності митця. Проаналізовано композиторський доробок Ф. Шопена у жанрі фортепіанного дуету для фортепіано у чотири руки та для двох фортепіано, створений у варшавський період творчості великого польського музиканта. Створено цілісну панораму ансамблевої виконавської діяльності Ф. Шопена (передусім у галузі фортепіанного ансамблю, а також віолончельного дуету $з$ фортепіано) у паризький період його життєтворчості. Охарактеризовано ансамблевий репертуар Ф. Шопена та визначено імена видатних музикантів - партнерів великого піаніста в сфері ансамблевого виконавства (суто фортепіанного та камерно-інструментального). Надано загальну характеристику камерноансамблевої спадщини композитора, репрезентованої переважно творами для віолончелі та фортепіано й за участю віолончелі. Визначено 
історичну роль, художнє значення та жанрові особливості творчого спадку Ф. Шопена у сфері ансамблевого фортепіанного та камерноінструментального мистецтва.

\section{ЛІТЕРАТУРА}

1. Бэлза И. История польской музыкальной культуры: В 3-х томах. Москва : Музыка, 1972. Т. 3. 234 с.

2. Зингер Е. Из истории фортепианного искусства Франции. Москва : Музыка, 1976. 112 с.

3. Ивашкевич Я. Шопен. Москва : Молодая гвардия, 1963. 304 с.

4. Кириллина Л. Сонатный цикл и сонатная форма в представлениях Бетховена. Музыкальный язык, жанр, стиль : сб. науч. трудов. Москва : Москов. Гос. консерватория им. П.И. Чайковского, 1987. С. 96-114.

5. Кремлев Ю. Фридерик Шопен: Очерк жизни и творчества. Изд. 3-е. Москва : Музыка, 1971. 408 с.

6. Николаев В.А. Шопен - педагог. Москва : Музыка, 1980. 93 с.

7. Польская И.И. Камерный ансамбль: история, теория, эстетика : монография. Харьков : ХДАК, 2001.396 с.

8. Польська I.I. Фортепіанний дует у системі фортепіанного ансамблю: жанрово-типологічні аспекти (The piano duet in the system of piano ensemble: genre-typological aspects). Культура України. Серія: Мистецтвознавство : зб. наук. пр. Харків. держ. акад. культури / за заг. ред. В.М. Шейка. Харків : ХДАК, 2018. Вип. 61. С. 167-178.

9. Соловцов А. Фридерик Шопен: Жизнь и творчество. Москва : Музгиз, 1960. $468 \mathrm{c.}$

10. Сорокина Е. Фортепианный дуэт: История жанра: Исслед. Москва : Музыка, 1988. 319 с.

11. Шопен Ф. Письма: В 2-х томах / Сост., вступ. ст., коммент., хронограф Г.С. Кухарского. 4-е изд. Москва : Музыка, 1989. Т. 1. 487 с.

12. Шопен Ф. Письма: В 2-х томах / Сост., авт. коммент, сост. указателей Г.С. Кухарского. 2-е изд., доп. Москва : Музыка, 1980. Т. 2 : Переводы. 468 с.

13. Шуман Р. О музыке и музыкантах: Собрание статей в 2-х томах / Пер. с нем. А.Г. Габричевского, Л.С. Товалевой; Сост., ред., вст. ст., коммент. и указ. Д.В. Житомирского. Москва : Музыка, 1975. Т. І. 407 с.

14. Jachimecki Zd. Chopin: rys życia i twórczości. Krakow: Polskie Wydawn. Muzyczne, 1957. 337 p.

15. Leichtentritt H. Friedrich Chopin. Berlin: Harmonie Verlag, 1920. $145 \mathrm{~s}$.

16. Prosnak J. Wariacje fletowe Chopina. Studia muzykologiczne. T. 1. Krakow : P.W.M., 1953. P. 267-307. 
17. Tomaszewski M. Cykl audycji "Fryderyka Chopina Dzieła Wszystkie". Polish Radio, program II. URL: https://en.chopin.nifc.pl/chopin/composition/ detail/id/11.

\section{Information about author:}

Polska I. I.,

Habilitated Doctor of Art Criticism, Professor, Professor at the Department of Theory and History of Music

Kharkiv State Academy of Culture

4, Bursatskyi Uzviz, Kharkiv, 61057, Ukraine 